Suppressing Thermal Energy Drift In The LLNL Flash X-Ray Accelerator Using Linear Disk Resistor Stacks

B. R. Kreitzer, T. L. Houck, O. C. Luchterhand

July 22, 2011

SUPPRESSING THERMAL ENERGY DRIFT IN THE LLNL FLASH X-RAY ACCELERATOR USING LINEAR DISK RESISTOR STACKS

Chicago, IL, United States

June 19, 2011 through June 23, 2011 
This document was prepared as an account of work sponsored by an agency of the United States government. Neither the United States government nor Lawrence Livermore National Security, LLC, nor any of their employees makes any warranty, expressed or implied, or assumes any legal liability or responsibility for the accuracy, completeness, or usefulness of any information, apparatus, product, or process disclosed, or represents that its use would not infringe privately owned rights. Reference herein to any specific commercial product, process, or service by trade name, trademark, manufacturer, or otherwise does not necessarily constitute or imply its endorsement, recommendation, or favoring by the United States government or Lawrence Livermore National Security, LLC. The views and opinions of authors expressed herein do not necessarily state or reflect those of the United States government or Lawrence Livermore National Security, LLC, and shall not be used for advertising or product endorsement purposes. 


\title{
SUPPRESSING THERMAL ENERGY DRIFT IN THE LLNL FLASH X-RAY ACCELERATOR USING LINEAR DISK RESISTOR STACKS
}

\author{
Blake R. Kreitzer, Timothy L. Houck, Otto C. Luchterhand \\ Lawrence Livermore National Laboratory \\ 7000 East Ave. Livermore, CA 94550
}

\begin{abstract}
This paper addresses thermal drift in sodium thiosulfate liquid resistors and their replacement with linear disk resistors from HVR Advanced Power Components. Sodium thiosulfate resistors in the FXR induction linear accelerator application have a temperature coefficient of $\sim 1.8 \% /{ }^{\circ} \mathrm{C}$. The FXR Marx banks send an $8 \mathrm{~kJ}$ pulse through eight $524 \mathrm{~cm}^{3}$ liquid resistors at a repetition rate of up to 1 every 45 seconds. Every pulse increases the temperature of the solution by $\sim 0.4^{\circ} \mathrm{C}$ which produces a $0.7 \%$ change in resistance. The typical cooling rate is $\sim 0.4^{\circ} \mathrm{C}$ per minute which results in $\sim 0.1 \%$ energy drop per pulse during continuous pulsed operations.

A radiographic accelerator is extraordinarily sensitive to energy variations. Changes in beam energy produce movement in beam transport, changes in spot size, and large dose variations. If self-heating were the only problem, we could predict the increase in input voltage required to compensate for the energy loss. However, there are other variables that influence the temperature of the resistors such as focus magnet heating, changes in room temperature, changes in cooling water, where the cell is located, etc. Additionally not all of the resistors have equivalent cooling rates and as many as 32 resistors are driven from a single power source.

The FXR accelerator group elected to replace the sodium thiosulfate resistors with HVR Linear Disk Resistors in a stack type configuration. With data limited for these resistors when used in oil and at low resistance values, a full characterization needed to be performed. High currents (up to $15 \mathrm{kA}$ ), high voltages (up to $400 \mathrm{kV}$ ), and Fast Rise times $(<10 \mathrm{~ns})$ made a resistor choice difficult. Other solid resistors have been tried and had problems at the connection points and with the fact that the resistivity changed as they absorbed oil. The selected HVR resistors have the advantage of being manufactured with the oil impregnated in to them so this characteristic is minimized while still offering the desired low temperature coefficient of resistance compared to sodium thiosulfate.

The characterization experiments and comparison with the sodium thiosulfate liquid resistors will be fully discussed and the final design described.
\end{abstract}

\section{LLNL'S FXR DESCRIPTION}

\section{A. Overview}

The Lawrence Livermore National Laboratory (LLNL) Flash X-Ray Radiography (FXR) machine [1] is a linear induction accelerator with a voltage output of $18 \mathrm{MeV}$ at a current of $3 \mathrm{kA}$. The electron beam is focused onto a tantalum target to produce $\mathrm{X}$-rays. The machine produces $>400$ rad X-rays in a 70 nS Pulse (FWHM) with a spot size of $\approx 1.6 \mathrm{~mm}$. These X-ray pulses are used regularly for radiographs of explosively-driven hydrodynamic experiments.

\section{B. Pulsed Power}

The pulsed power for the system (cf. Fig. 1) consists of 12 Marx banks with $101-\mu \mathrm{F}$ capacitors in each bank, half of which are charged in parallel positively, and the other half are negatively charged in parallel. The charge voltage can be varied from $\pm 30 \mathrm{kV}$ to $\pm 40 \mathrm{kV}$. The Marx capacitors are fired in series into the Blumleins with up to $400 \mathrm{kV} 2 \mu \mathrm{S}$ output.

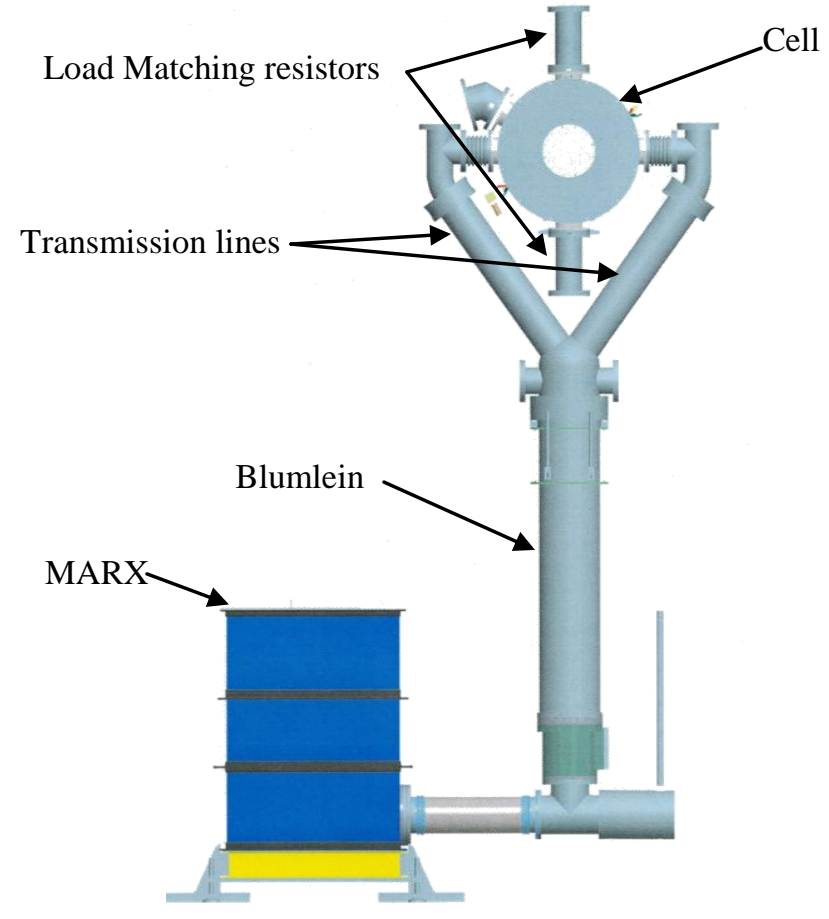

Figure 1 FXR Pulsed Power Chain 
Each Marx drives from 4 to 6 Blumleins that further shape the pulse to the cell. The Blumlein impedance is $11 \Omega$. The transmission lines (or Y's) transport the energy to the cell and their impedance is also $11 \Omega$.

Each ferrite-loaded cell is an inductive load that imparts its energy to the beam. The Injector (the part of the accelerator that creates the beam, also called the diode) is impendence matched with two $22 \Omega$ load matching resistors for unity gain. The accelerator (or induction part) is matched up with two $44 \Omega$ resistors for a voltage gain.

The $2 \mu$ s pulse from the Marx bank charges through the Blumleins and cells. Then, at the appropriate time, are fired down by the Stage III switch causing the negative $80 \mathrm{nS}$ pulse (an oscillograph of which is shown in Fig. 2) at the gap. (70nS for the Injector)

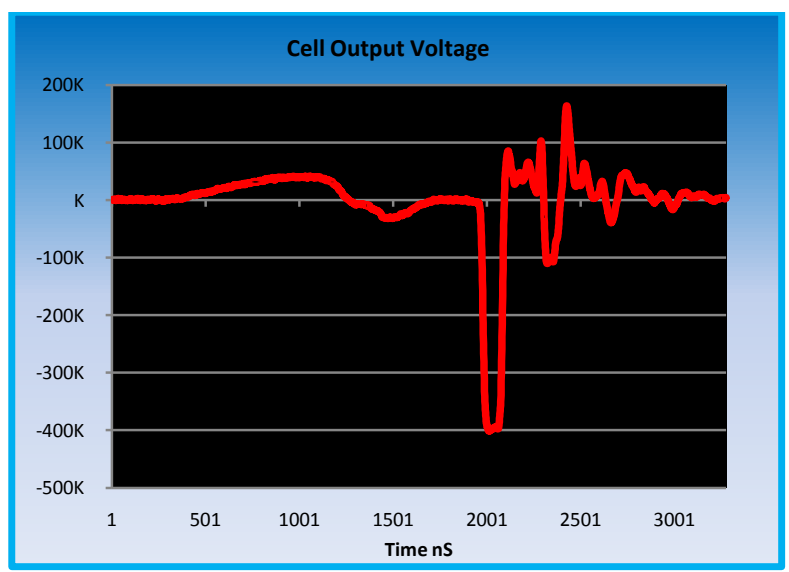

Figure 2. Cell Monitor Gap Voltage Signal

\section{REASON FOR CHANGE}

\section{A. Overview}

During operation of the FXR it was noticed that energy seemed to drift over time. After installing a database and then trending the drift we were able to correlate the drift with other influences. The primary influence was self-heating of the load matching resistors. Other influences include cooling water temperature, whether the focus magnets were on, and ambient temperature. With this trending we also found that the problem was worse than we expected. (You know the old story, throw a frog into hot water and he will jump out. Put a frog in cold water then heat it up, frog stew.) Cell voltage was dynamic throughout the day. The root cause was determined to be the large temperature coefficient $(1.8 \% / \mathrm{K})$ of the liquid sodium thiosulfate cell matching resistors

\section{B. Cell Voltage Directly Affects Beam Energy}

After the injector stage, every cell adds its gap voltage as energy to the beam. If all cells are down in voltage then the Beam energy will be down.

\section{Beam Energy Affects Beam Transport}

Steering Magnets steer the beam down the beam pipe. The steering magnets are tuned for specific beam energy at each point in the machine. If the beam energy drifts, the steering has to be retuned throughout the day.

\section{Beam Energy Affects X-Ray Dose}

The X-Ray dose is affected by beam energy. Dose rate is determined by the beam current multiplied by energy of the electrons raised to approximately the 2.6 power. Also note that the sodium thiosulfate resistors are also used in the injector which means that beam current drops also. So in a 33 shot run on FXR we saw $3 \%$ loss in beam energy which resulted in a $15 \%$ loss in $\mathrm{X}$-ray dose.

$$
\mathbf{E}(\mathbf{t})=\mathrm{e}^{*} *\left(\mathbf{V}_{\text {injector }}+\mathbf{V}_{\text {accelerator }}-\mathbf{V}_{\text {beam }}\right)
$$

X-Ray Dose $=k(I * E 2.6) \Delta t$

Figure 3. Basic Dose Equations

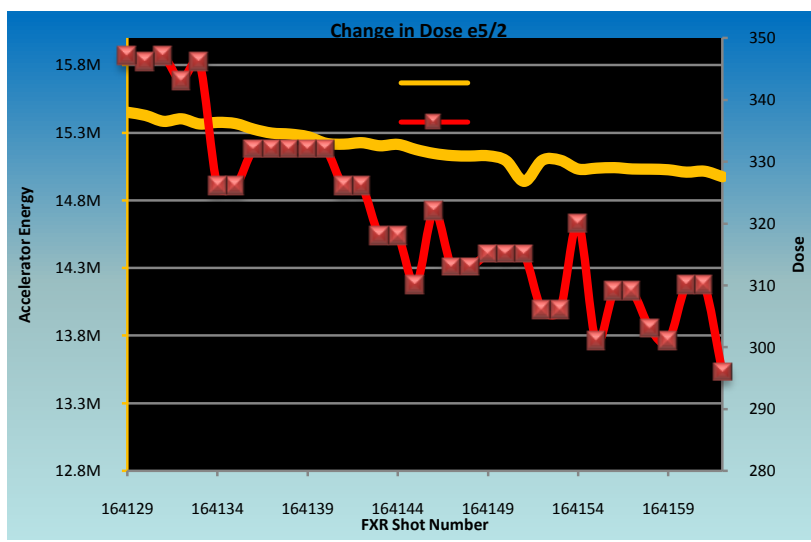

Figure 4. Energy Loss and Dose vs. shot number

\section{E. Beam Energy Affects X-Ray Spot Size}

A small X-Ray spot size is essential to a high resolution X-ray image. The radius of the X-ray source is affected by a number of electron beam parameters and accelerator component characteristics such as emittance, energy-variation, chromatic aberration, and beam motion. Energy variation is a key element in spot size. The accelerator final focus magnet is tuned for a fixed beam energy to give us a small spot size. If the beam energy is too great (cf. Fig 4) the spot is under focused and gives us a larger spot size. If the energy is too low then the beam is over focused and gives us a larger spot size. 


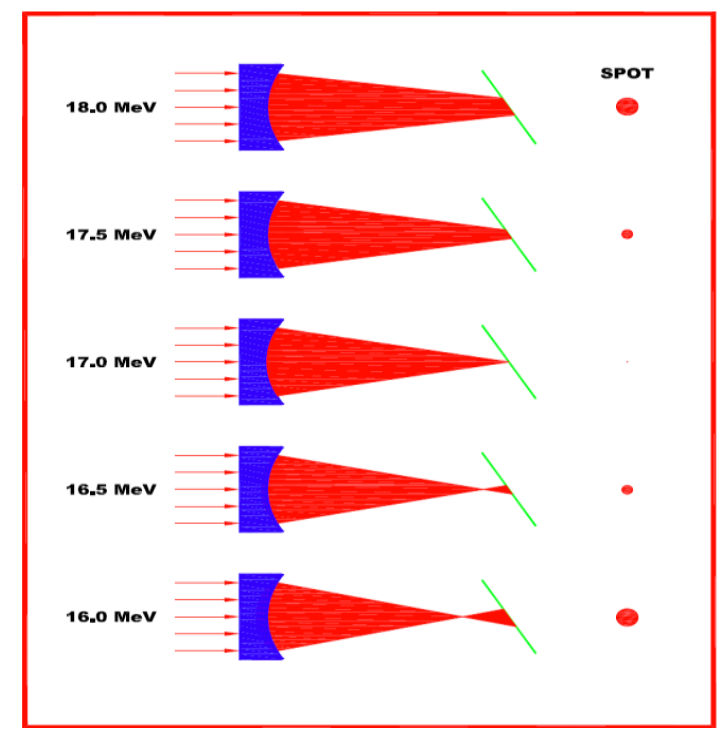

Figure 4. Beam Focus Cartoon

\section{III.RESISTOR DESIGN}

Due to different cell cooling rates and other variables it is simpler to change the resistor than develop an algorithm to control charge voltage to maintain beam energy particularly since our charge supplies drive as many as 16 cells each and we would only be able to average the energy as opposed to stabilizing each cell.

The key design elements used are the 11 HVR solid disk resistors arranged in a stack. They were chosen for their low thermal resistance coefficient, their high energy rating, their large connections, and the fact that they are oil impregnated during manufacture. Oil impregnation keeps the resistors from changing their value while used in oil. Other key elements (see Figure 5) are the non-fibrous Torlon 4203 support rod, a Belleville Washer that maintains $1600 \mathrm{lbs}$ of force on the assembly, and the crush gaskets that fill the voids for uniform current flow.

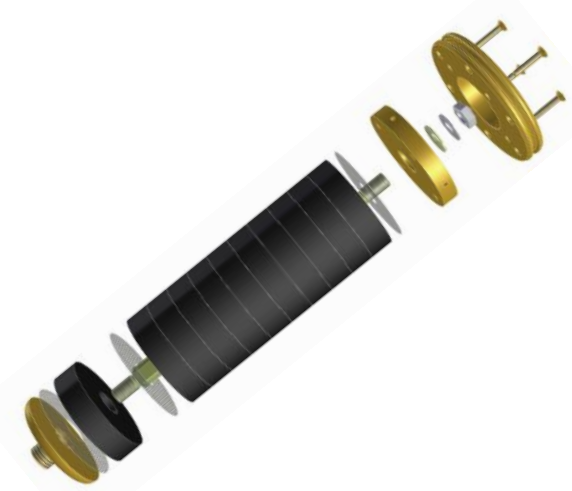

Figure 5. Resistor Assembly Exploded View

\section{IV.TEST RESULTS}

Many tests were done on these Resistor assemblies to qualify them to be installed into our Accelerator.

\section{A. Voltage Drift Tests}

The most significant tests were for voltage stability or low thermal resistance coefficient. For these tests we simply built two assemblies and ran them in the FXR test stand [2]. (Our test stand is simply a one cell entire pulsed power chain.) In the first test we fired 200 shots at normal voltage $(380 \mathrm{kV})$ and rep rate of 1 every 45 sec. and compared it to FXR data run at the same parameters. As seen in Figure 6, the solid resistor voltage merely changed $+0.04 \%$ while the liquid resistor voltage changed $-9.5 \%$.

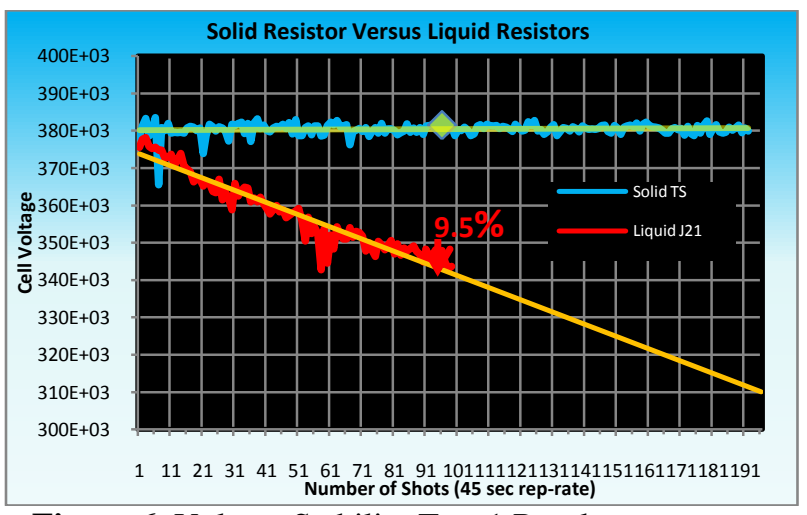

Figure 6. Voltage Stability Test 1 Resalts

Then we ran the resistors at $110 \%(440 \mathrm{kV})$ for 628 shots (full day) at normal rep-rate. The results are shown below in Figure 7. One can see a slight drop in cell voltage although we were expecting a rise. After investigating the droop we found that it could be traced to an unrelated drift in timing elsewhere in the chain.

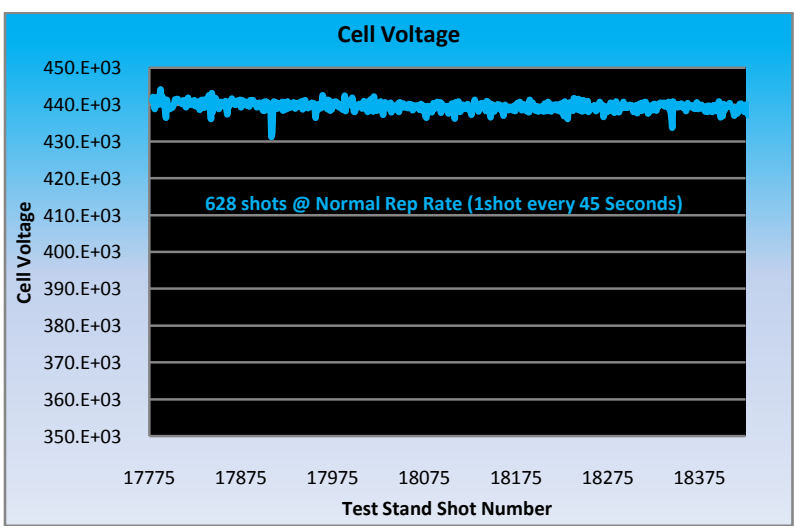

Figure 7. Voltage Stability Test 2 Resalts

Another very important question is whether the output cell flattop is adversley affected. Figure 8 shows that the cell output is not adversly affected. 


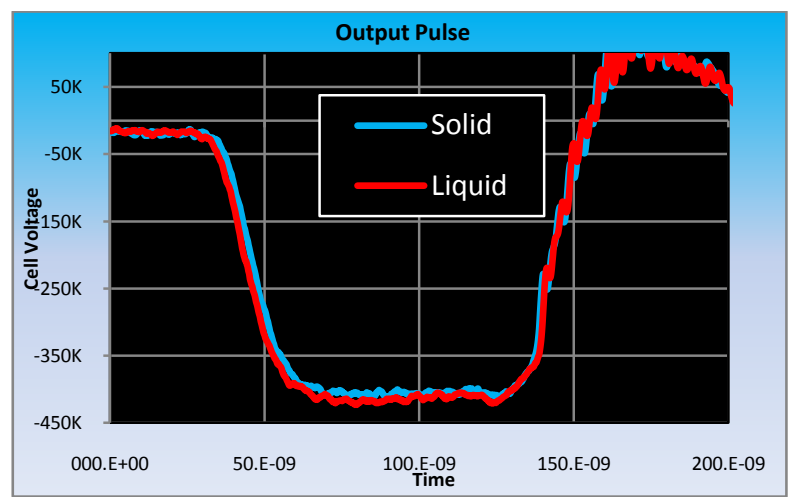

Figure 8. Cell Output Comparison

\section{B. Over Voltage Tests}

To provide a very conservative safety margin, we wanted to test then to at least $200 \%$ voltage. However, the FXR test stand could not pulse these 44ohm resistors with $800 \mathrm{kV}$. We came up with an alternate plan to test to these voltages. We built two $20 \mathrm{ohm}$ stacks (Figure 8, five $4 \mathrm{ohm}$ disks) and ran them to as much voltage as we could get out of the test sand. The results are shown in Figure 9. Over 200 shots were logged at greater than $800 \mathrm{kV}$ equivlant, with no damage or breakdowns

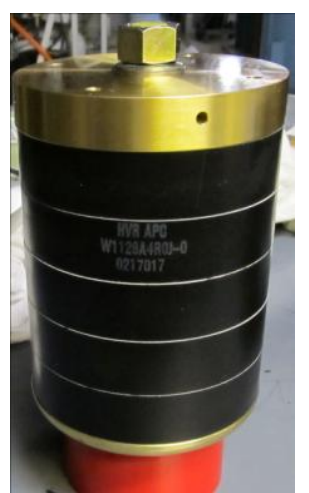

Figure 8. Short Stack of five 4 Ohm Resistors

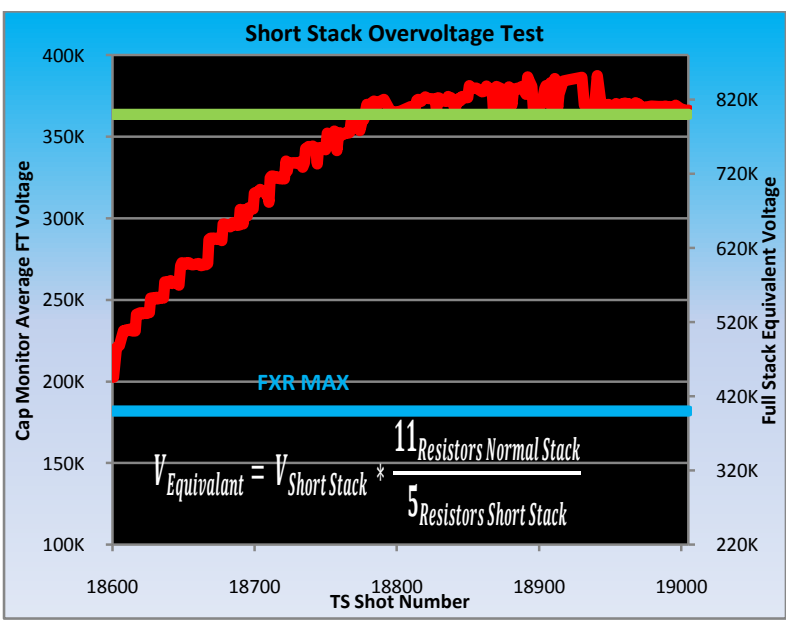

Figure 9. Short Stack of five 4 Ohm Resistors

\section{Over Current Tests}

Again we did not have at capacity to test the full resistor stacks to $200 \%$ Injector Current. (Injector current is higher than accelerator current) So we built a single $10 \mathrm{Ohm}$ stack (five $2 \mathrm{Ohm}$ pucks). Since the test stand does not propagate beam it does not have to be driven symmetrically. We pulsed the test stand at full output and the result is shown below in Figure 10. More than 50 shots at greater than 200\% injector current were logged. Current was calculated by diving cell voltage by the known $10 \mathrm{Ohm}$ load.

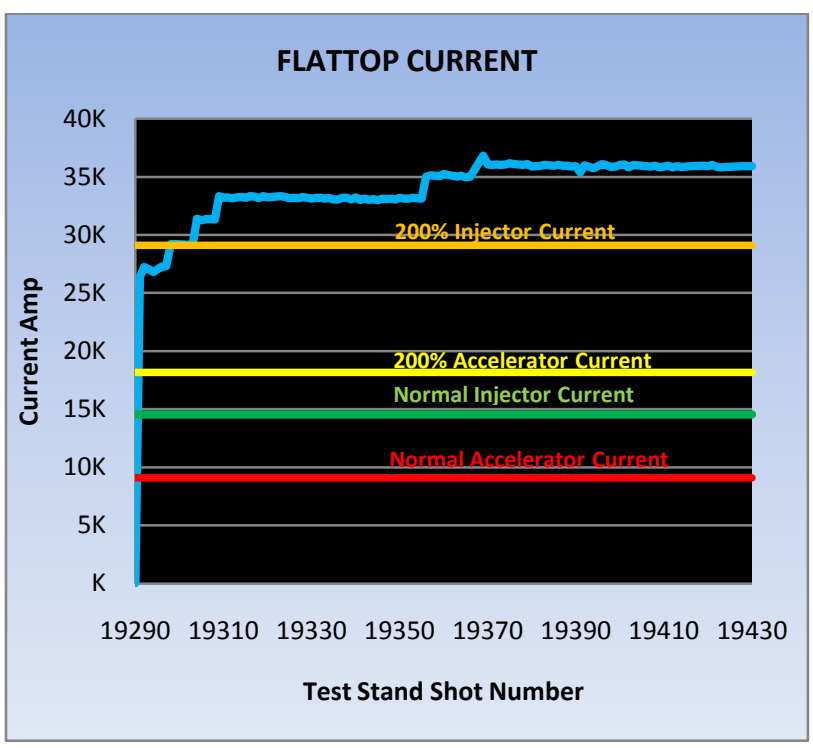

Figure 10. 1 Short Stack of five 2Ohm Resistors

\section{Power And Energy}

Energy and Power have been calculated and the results are below.

\begin{tabular}{|c|c|c|c|c|c|c|c|}
\hline & & \multicolumn{4}{|c|}{ FXR Normal } & \multirow{2}{*}{ MAX Tested } & \multirow{2}{*}{$\%$ of FXR } \\
\hline & & I & $\mathbf{J}$ & $\mathbf{K}$ & $\mathbf{L}$ & & \\
\hline Peak Voltage & $\mathrm{v}$ & $320.0 \mathrm{E}+3$ & $380.0 \mathrm{E}+3$ & $405.0 \mathrm{E}+3$ & $400.0 \mathrm{E}+3$ & $854.0 \mathrm{E}+3$ & 211 \\
\hline Peak Current & $\mathrm{A}$ & $14.5 \mathrm{E}+3$ & $8.6 \mathrm{E}+3$ & $9.2 \mathrm{E}+3$ & $9.1 \mathrm{E}+3$ & $36.0 \mathrm{E}+3$ & 248 \\
\hline $\begin{array}{l}\text { Peak Current } \\
\text { Density 102cm }\end{array}$ & $\mathrm{A} / \mathrm{cm}^{2}$ & $190.4 \mathrm{E}+0$ & $113.0 \mathrm{E}+0$ & $120.5 \mathrm{E}+0$ & $119.0 \mathrm{E}+0$ & $471.2 \mathrm{E}+0$ & 248 \\
\hline $\begin{array}{l}\text { Peak Current } \\
\text { Density } 112 \mathrm{~cm}\end{array}$ & $\mathrm{~A} / \mathrm{cm}^{2}$ & $156.0 \mathrm{E}+0$ & $92.7 \mathrm{E}+0$ & $98.7 \mathrm{E}+0$ & $97.5 \mathrm{E}+0$ & 471.2E+0 & 302 \\
\hline Peak Power & $\mathrm{w}$ & $4.7 \mathrm{E}+9$ & $3.3 \mathrm{E}+9$ & $3.7 \mathrm{E}+9$ & $3.6 \mathrm{E}+9$ & $13.0 \mathrm{E}+9$ & 278 \\
\hline $\begin{array}{l}\text { Peak Power } \\
\text { Density 102cm }\end{array}$ & $\mathrm{W} / \mathrm{cm}^{3}$ & $2.2 \mathrm{E}+6$ & $1.5 \mathrm{E}+6$ & $1.7 \mathrm{E}+6$ & $1.7 \mathrm{E}+6$ & $11.0 \mathrm{E}+6$ & 504 \\
\hline $\begin{array}{l}\text { Peak Power } \\
\text { Density 112cm }\end{array}$ & $\mathrm{W} / \mathrm{cm}^{3}$ & $1.8 \mathrm{E}+6$ & $1.3 \mathrm{E}+6$ & $1.4 \mathrm{E}+6$ & $1.4 \mathrm{E}+6$ & $11.0 \mathrm{E}+6$ & 615 \\
\hline Energy & $\mathrm{J}$ & 512 & 571 & 833 & 810 & 1902 & 228 \\
\hline $\begin{array}{l}\text { Energy Density } \\
102 \mathrm{~cm}\end{array}$ & $\mathrm{~J} / \mathrm{cm}^{3}$ & 239.8E-3 & $267.5 \mathrm{E}-3$ & $390.2 \mathrm{E}-3$ & $379.4 \mathrm{E}-3$ & $2.0 \mathrm{E}+0$ & 502 \\
\hline $\begin{array}{l}\text { Energy } \\
112 \mathrm{~cm}\end{array}$ & $\mathrm{~J} / \mathrm{cm}^{3}$ & 196.6E-3 & 219.3E-3 & 319.9E-3 & 311.0E-3 & $2.0 \mathrm{E}+0$ & 613 \\
\hline
\end{tabular}

Figure 11. Eletrical Test spread sheet 


\section{Summary}

We have tested these resistors to an extent that we are implementing them into our FXR Accelerator. We expect to see great gains in stability, repeatability and decrease in maintenance cost.

I would like to thank the following people for their contribution to this paper. : Ron Arganbright, Bennett Waite, W. J. DeHope, Mike Ong, Jan Zentler, Jim Dunlap, Kett Gifford, Tom McWilliams

\section{VI.REFERENCES}

[1] B. Kulke, et al, "Initial Performance Parameters on FXR", in Proc IEEE 15th Power Modulator

Symposium, Baltimore, MD, June, 1982

[2] W.J. DeHope, et al, "An Induction Linac Test Stand", in Proc Particle Accelerator Conference, Knoxville, TN, May 2005,

This work performed under the auspices of the U.S. Department of Energy by Lawrence Livermore National Laboratory under Contract DE-AC52-07NA27344. 